\title{
Jefferson
}

Thomas Jefferson University

$\overline{\text { HOME OF SIDNEY KIMMEL MEDICAL COLLEGE }}$

JHN Journal

Volume 14

Issue 1 Summer 2019

Article 2

Summer 2019

\section{Spinal Cord Injury: Current and Novel Treatment Strategies}

Anthony Stefanelli, MD

Thomas Jefferson University

Umma Fatema

Thomas Jefferson University

Alexandra Emes

Thomas Jefferson University

James Harrop, MD, FACS

Thomas Jefferson University

Follow this and additional works at: https://jdc.jefferson.edu/jhnj

Let us know how access to this document benefits you

\section{Recommended Citation}

Stefanelli, MD, Anthony; Fatema, Umma; Emes, Alexandra; and Harrop, MD, FACS, James (2019) "Spinal Cord Injury: Current and Novel Treatment Strategies," JHN Journal: Vol. 14 : Iss. 1 , Article 2.

DOI: https://doi.org/10.29046/JHNJ.014.1.002

Available at: https://jdc.jefferson.edu/jhnj/vol14/iss1/2

This Article is brought to you for free and open access by the Jefferson Digital Commons. The Jefferson Digital Commons is a service of Thomas Jefferson University's Center for Teaching and Learning (CTL). The Commons is a showcase for Jefferson books and journals, peer-reviewed scholarly publications, unique historical collections from the University archives, and teaching tools. The Jefferson Digital Commons allows researchers and interested readers anywhere in the world to learn about and keep up to date with Jefferson scholarship. This article has been accepted for inclusion in JHN Journal by an authorized administrator of the Jefferson Digital Commons. For more information, please contact: JeffersonDigitalCommons@jefferson.edu. 


\section{Spinal Cord Injury: Current and Novel Treatment Strategies}

Anthony Stefanelli, MD; Umma Fatema²; Alexandra Emes²; James Harrop, MD¹, FACS

${ }^{1}$ Department of Neurological Surgery, Thomas Jefferson University, Philadelphia, PA, 19107 2 Department of Neurological Surgery, Sidney Kimmel Medical College, Thomas Jefferson University, Philadelphia, PA 19107

\section{INTRODUCTION}

The care and treatment of spinal cord injury (SCI) patients has significantly evolved over the last several decades. There has been great interest and promising research conducted over this period resulting in advancement of our understanding of the pathophysiology of $\mathrm{SCl}$ on both a biochemical and biomolecular level. Concurrently, there has also been rapid clinical advancements in treating spinal fractures with improvement in the understanding of the biomechanics of injuries, as well as improvements in spinal fixation techniques and devices. In addition, there have been great strides made in the collaborative care and treatment efforts of $\mathrm{SCl}$ patients particularly in the fields of radiology, rehabilitation, trauma, and intensive care.

The developments in $\mathrm{SCl}$ treatment have led to a decrease in the overall incidence of traumatic injuries, particularly in the younger populations. This is mainly a result of preventative measures and education by the various foundations who focus on the treatment of $\mathrm{SCI}$ patients such as CSRS, ASIA, AAOS, CNS, and AANS. In addition, there has been a greater emphasis in society on limiting catastrophic injuries such as through the use of: airbag immobilization in motor vehicles, helmets, and the overall reduction of high-risk activities.

To provide some background information on the pathophysiology of a traumatic $\mathrm{SCl}$, it is believed that $\mathrm{SCl}$ is multifaceted, with the initial force or compression of the cord resulting in the primary injury. This is then followed by an inflammatory or biochemical response that results in further injury to the cord over the subsequent days to weeks. This is referred to as the secondary injury, and it is this stage of injury that has been the target of intense research. Currently, there exists multiple novel strategies in dealing with this secondary injury component including surgical techniques, medical management, pharmacology, and cell-based therapies which will be discussed below.

\section{SURGICAL TECHNIQUES}

Over the last century, it is been established that early decompression of the spinal cord results in improved neurologic outcomes. However, not until the publication of the STASCIS study (PLoSOne. 2013 Aug 23;8(8):e72659) has clinical data significantly demonstrated that early decompression does, indeed, improve neurological outcome. This study, in which Jefferson Health was the highest enrolled center, showed that surgical decompression and stabilization in less than 24 hours gave the patient the greatest chance of improving by up to two neurologic grades in the ASIA scale.

Another area of exciting research has been the use of a biocompatible scaffold polymers for acute spinal cord injury, which is also an option for patients at Jefferson Health. This scaffold is surgically inserted into the spinal cord at the site of injury and will break down over several weeks. It is postulated that this polymer modulates the healing environment in acute injury and provides the structural support in both acute and chronic injury necessary to promote a local environment supportive of cell survival and growth within the spinal cord. The INSPIRE trial, a study from InVivo therapeutics (http://www.invivotherapeutics.com) examined the potential benefit of this NeuroSpinal Scaffold (TM) for safety and neurologic recovery in patients with complete

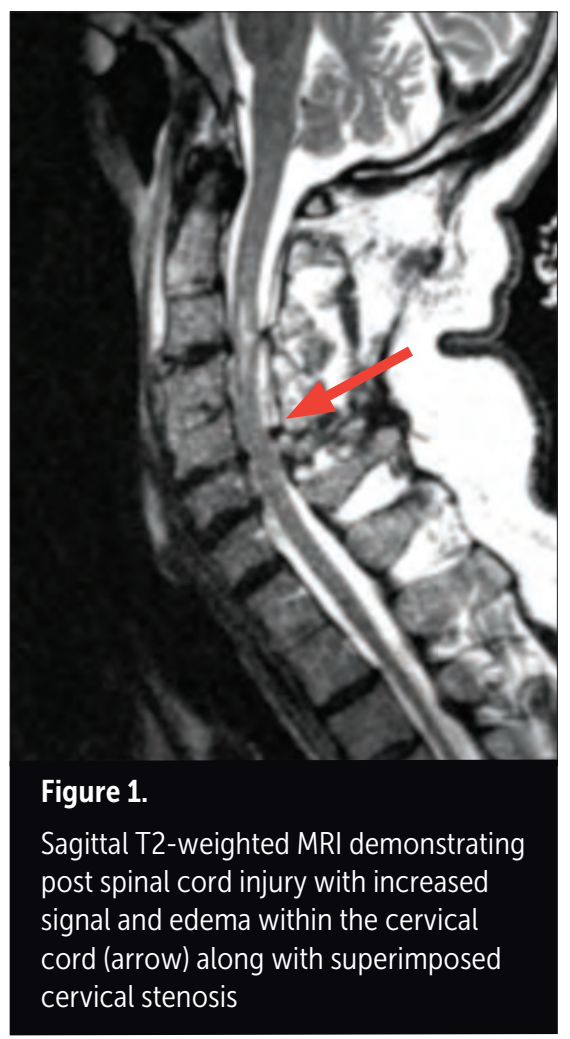

thoracic (T2-T12) spinal cord injury. This study is currently being analyzed and there appears to be a neurologic benefit with use of this polymer scaffold. Larger and more comprehensive studies will likely take place following final analysis of the data from this trial.

\section{MEDICAL MANAGEMENT}

The medical intensive care treatment of the patients after their traumatic $\mathrm{SCl}$ is also extremely important in overall recovery and prognosis. It has been determined throughout the last several decades that increased blood flow to the spinal cord by maintaining patients with an elevated mean arterial pressure significantly improves neurologic recovery. This is akin to elevating the blood pressure in an acute stroke patient so as to perfuse the brain penumbra that has not yet reached 


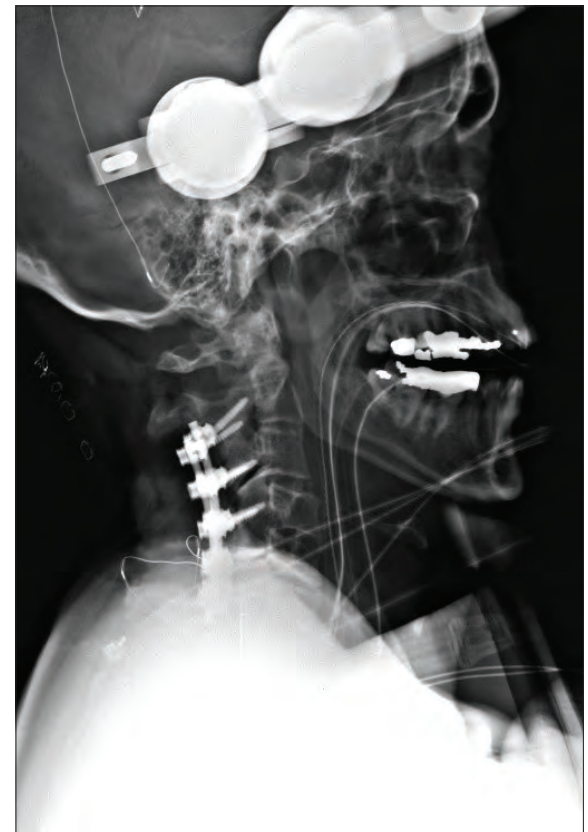

Figure 2.

Intraoperative lateral radiograph

demonstrating post-surgical instrumented posterior cervical fusion hardware

terminal ischemia. In addition, there is interest in the use of hypothermia to decrease the metabolic bands of the spinal cord during the acute phase of injury to help aid in recovery. Jefferson is currently involved in this study through a grant from the Department of Defense.

\section{PHARMACOLOGY}

The largest international SCI pharmacological multicentered prospective randomized controlled study is presently being run through the $\mathrm{AO}$ Foundation. Jefferson is currently the largest clinical enrolling site in North America. This study is investigating the drug, Riluzole, which is approved for patients with ALS, and its effect on reducing excitatory apoptosis (cell-initiated death) after an injury to the spinal cord. This is a continuation of a phase 1 study, also done at Jefferson, which showed safety of the medication.

Unfortunately, not all promising initial studies are confirmed during their phase 3 trials. Recently, Jefferson was involved with the Vertex $\mathrm{SCl}$ trial which examined a medication to prevent cell apoptosis
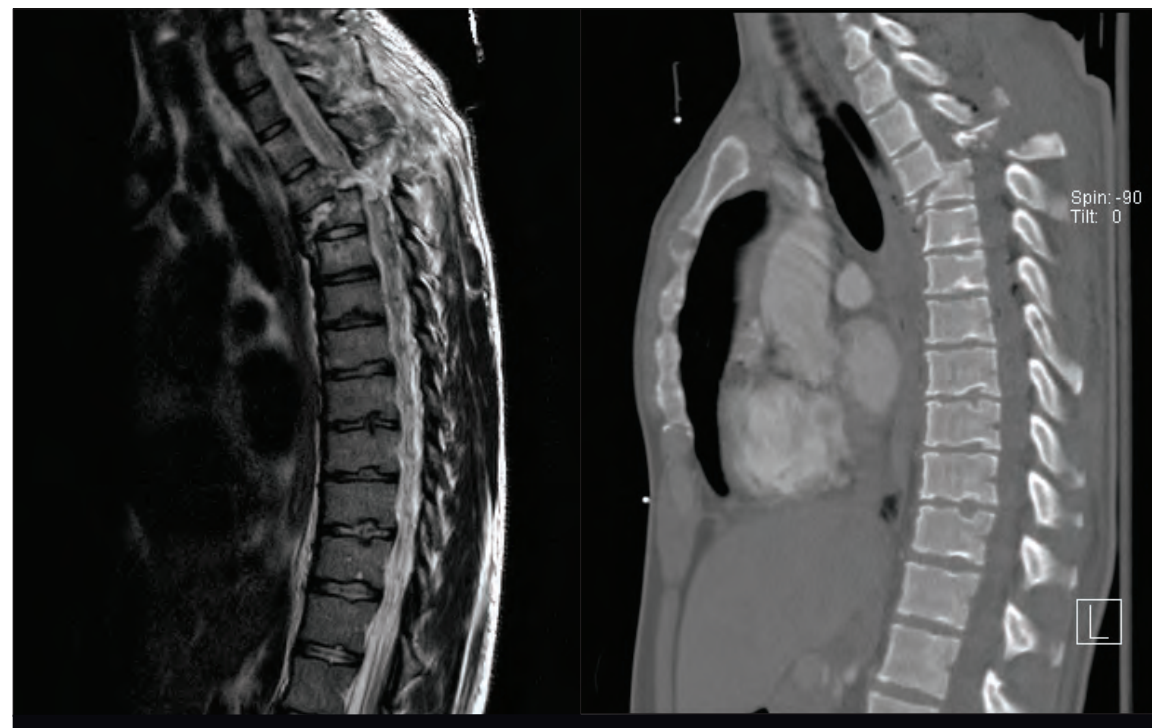

Figure 3.

(Left) Sagittal T2-weighted MRI and (Right) CT scan demonstrating a thoracic flexiondistraction injury (fracture dislocation) causing severe spinal cord compression

by blocking the rho activation system. In the initial phase 1 study, which compared the medication to case controls, not only was the medication safe, but it also showed to be efficacy. Unfortunately, when the medication was compared to placebo there was no significant improvement, so the trial was ultimately halted. However, the study did result in greater interest in the investigation of drugs to treat and modulate injuries to the spinal cord.

\section{CELL-BASED THERAPIES}

There is a good deal of excitement about the possibility of cell mediated interventions being used to improve neurologic outcomes after $\mathrm{SCl}$. We are very fortunate at Jefferson to have been asked to participate in many studies investigating this topic and strategy. The first stem cell spinal cord injury trials were performed by Geron Corporation, although, they were eventually halted and sold to a secondary company that became known as Asterias (https://asteriasbiotherapeutics.com). Asterias has been a proponent of intraparenchymal spinal cord injection of stem cells. Unlike some other cell-based strategies, these do not target the neurons directly but rather the oligodendrocytes, which function to provide support and myelin production in the central nervous system.

In another trial, named the StemCell Inc trial, HuCNS stem cells were implanted through direct spinal cord parenchymal injections within one year of the injury. Despite showing promising improvements in neurologic recovery, the study was unfortunately halted due to financial issues.

Currently, there is an active trial investigating the use of Schwann cell transplants being performed at the University of Miami. This study uses Schwann cells harvested from the patient and transfers them directly into spinal cord injury site. The results of the phase 1 portion of this trial were published in 2017 and showed the safety of this treatment, noting that there were no adverse events or serious adverse events related to the cell therapy.

It is important to realize, however, that that with any new treatment, there can be significant complications. Particularly related to cell-based therapies, such as implantation of stem cells, there is the possibility for inducing aberrant growth of non-spinal cord tissue which has potential to harm the surrounding neural structures. 


\section{CONCLUSION}

Although the overall incidence of spinal cord injury is decreasing in our population, it is still a major public health concern. The costs associated with treating and caring for patients with spinal cord injuries is quite significant. Currently, there is no "cure" that exists which allows the spinal cord to regenerate and heal completely after a traumatic injury, making many of these injuries devastating to the patients and their families. However, with advancements in surgical, medical, and pharmacological research coming to fruition at a rapid pace, the outlook on evolving the care of these patients and their injuries is promising.

\section{REFERENCES}

1. Ho CH, Wuermser LA, Priebe MM, Chiodo AE, Scelza WM, Kirshblum SC (March 2007) "Spinal cord injury medicine. 1. Epidemiology and classification". Archives of Physical Medicine and Rehabilitation. 88 (3 Suppl 1): S49-54. doi:10.1016/j.apmr.2006.12.001. PMID 17321849

2. Krucoff MO, Miller JP, Saxena T, Bellamkonda R, Rahimpour S, Harward SC, Lad SP, Turner DA (January 2019). "Toward Functional Restoration of the Central Nervous System: A Review of Translational Neuroscience Principles". Neurosurgery. 84 (1): 3040 doi:10.1093/neuros/nyy128. PMC 6292792. PMID 29800461.

3. Kabu S, Gao Y, Kwon BK, Labhasetwar V (December 2015). "Drug delivery, cell-based therapies, and tissue engineering approaches for spinal cord injury". Journal of Controlled Release. 219: 141-154. doi:10.1016/j. jconrel.2015.08.060. PMC 4656085. PMID 26343846.

4. Marino RJ, Barros T, Biering-Sorensen F, Burns SP, Donovan WH, Graves DE, Haak M, Hudson LM, Priebe MM (2003). "International standards for neurological classification of spinal cord injury". The Journal of Spinal Cord Medicine. 26 Suppl 1: S50-6. doi:10.1080/107 90268.2003.11754575. PMID 16296564
5. Newman MF, Fleisher LA, Fink MP (2008). Perioperative Medicine: Managing for Outcome. Elsevier Health Sciences. ISBN 978-1-4160-2456-9.

6. Silva NA, Sousa N, Reis RL, Salgado AJ (March 2014). "From basics to clinical: a comprehensive review on spinal cord injury". Progress in Neurobiology. 114: 25-57. doi:10.1016/j.pneurobio.2013.11.002. PMID 24269804.

7. Wirth, Edward (September 14, 2016). "Initial Clinical Trials of hESC-Derived Oligodendrocyte Progenitor Cells in Subacute Spinal Cord Injury" (PDF). ISCoS Meeting presentation. Asterias Biotherapeutics.

8. Witiw CD, Fehlings MG (July 2015). "Acute Spinal Cord Injury". Journal of Spinal Disorders \& Techniques. 28 (6): 202-10. doi:10.1097/BSD.0000000000000287. PMID 26098670

9. Yu WY, He DW (September 2015). "Current trends in spinal cord injury repair". European Review for Medical and Pharmacological Sciences. 19(18): 3340-4. PMID 26439026. 